\title{
An Analysis Bankruptcy Prediction on Stock Price Through Earnings Per Share at PT. Bank Mandiri (Persero) Tbk.
}

\author{
Fahmi Mauludin ${ }^{1}$, Nor Norisanti and Erry Sunarya ${ }^{3}$ \\ ${ }^{123}$ Muhammadiyah University of Sukabumi
}

fahmim73@gmail.com

\begin{abstract}
This study aims to measure the effect of bankruptcy predictions on the stock price and earning per share as an intervening variable. The object used is PT. Bank Mandiri (Persero) Tbk. and data used is secondary data containing the company's monthly financial statements from 2016-2019 and stock data from Indonesia Stock Exchange. This study uses path analysis with SPSS program. The results of the study show that bankruptcy predictions have a direct and significant effect on stock prices, and bankruptcy predictions have an indirect and significant effect on stock prices through earnings per share.

Keywords: Bankruptcy Prediction, Stock Price, Earning Per Share.
\end{abstract}

JEL $\quad:$ G14

DOI : 10.24002/kinerja.v21i2.3138

Received : 07/03/2020 Reviewed: 07/10/2020 Final Version: 07/10/2020

\section{INTRODUCTION}

The stock price is seen as a measure of company value, this is shown in the results agreed by the company in running its business, stock prices can change at any time due to several factors, one of the factors that increase the stock price is bankruptcy. The bankruptcy of the company becomes important for investors in making decisions, besides that some problems or rumors are information about the company, where the information can affect investors who will invest their money or not.

Information about the company's financial data that has go public is information that is open for the public and who want to find out financial information from the company, this information can be used to receive investments given on each share or also the company's stock price. The value of the company can support the company's stock price which can be seen from the company's ability to reach his goal, namely to benefit from its operational activities. But other things can 
change the company's stock price, one of the cases that occurred at PT. Bank Mandiri (Persero) Tbk. in August 2019 after publishing the second quarter financial statements by recording a profit of 13.5 trillion rupiahs. Bank Mandiri (Persero) Tbk. make the stock price dominant go down.

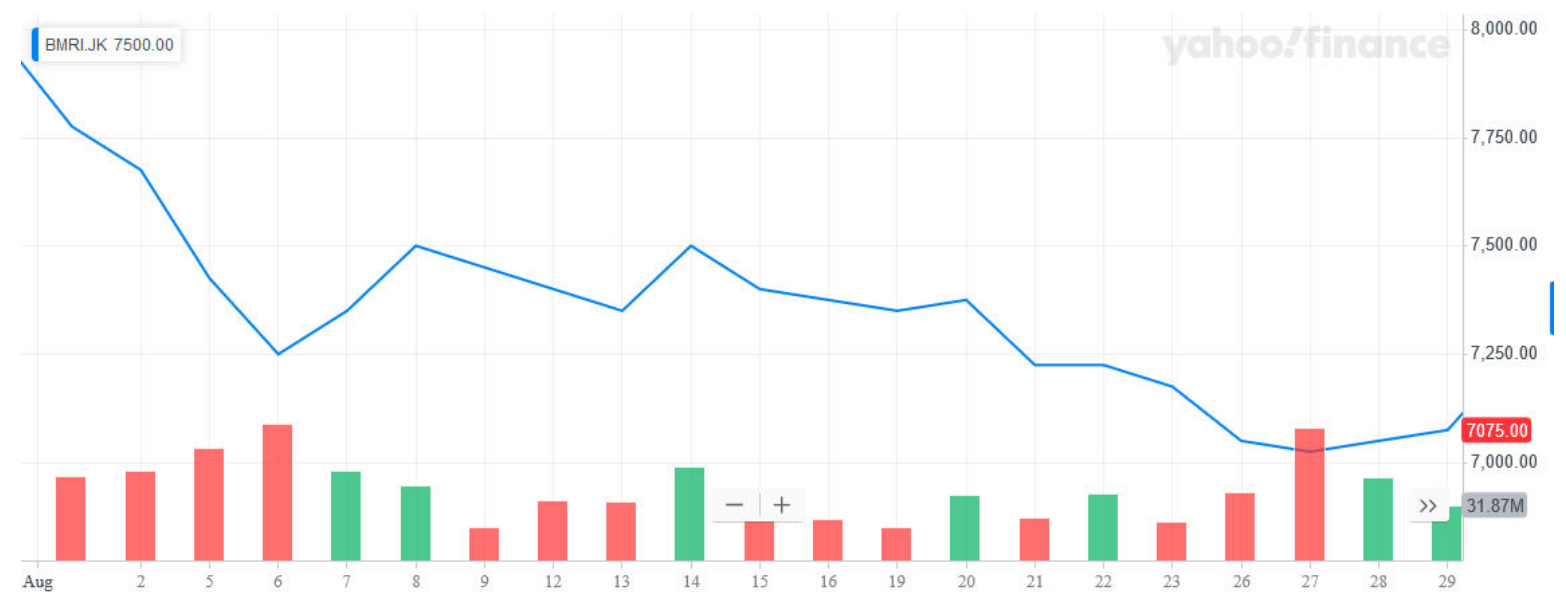

Figure 1. Stock Price Chart PT. Bank Mandiri (Persero) Tbk. on Aug 2019 Source: finance.yahoo.com

The bankruptcy of a company is important for investors to choose the decision to keep company stock before the stock price move down, ways to predict bankruptcy, one of them by analyzing the financial statements of a company with bankruptcy prediction methods. Also, some factors affect changes in stock prices, that is earnings per share. To predict stock prices sometimes have to think about several aspects before deciding to buy or sell stock where stock prices tend to be unstable due to several factors.

According to Wiyarni (2018), the value of the z-score bankruptcy prediction model has positively influenced the stock price, it is consistent with Syamni, Majid and Siregar (2018), showed bankruptcy prediction model can be utilized as one of the ways to measure movement stock price. And earning per shares effect on stock price (Velankar, Chandani and Ahuja, 2017). The result of research from Velankar, Chandani and Ahuja, (2017) consistent with Pradhan and Paudel (2016), showed earning per share are positively related to the stock price. Then for that reason, the author will analyze the effect of bankruptcy predictions on stock prices and earnings per share as an intervening variable.

\section{LITERATURE REVIEW}

\subsection{Bankruptcy Prediction}

Bankruptcy prediction is a way to predict whether a company will a bankruptcy or not in the future, otherwise, it can be used to measure the level of health of the 
company. Bankruptcy is a legitimate status of an individual or other association that can't reimburse their obligations to lenders (Panchal et al., 2019). Bankruptcy is a condition that is very much avoided for legal entities with business activities (Nuryanto, Sulistiyono and Pujiono, 2019). Bankruptcy is a condition of indebtedness where an organization or an association can't release its money related commitment or can't meet the installments to their leasers (Kapil and Agarwal, 2019). Bankruptcy is the point at which an individual intentionally announces himself as an indebted and goes to the court. On announcing him as bankrupt, the court is dependable to exchange the individual property of the ruined and hand it out to its lenders. It gives a crisp rent of life to the indebted (Sharma and Vyas, 2017).

\subsection{Earnings Per Share}

Earnings per share or commonly abbreviated as EPS is profit derived from each share issued. Earning per share speaks to the ability of an organization in making benefit for each stock possessed by stakeholder. The increasing earning per share for the most part shows the development of an organization and bringing about high market cost (Pradhan and Paudel, 2016). Earning per share is classified as a market ratio, which is one indicator to measure which stocks have the potential to benefit investors (Puspita, 2017). based on the theory above, earning per share is a ratio to measure how much profit will be obtained by investors from each share that comes from the company's revenue and it can be concluded that every income earned by the company in its operations will be distributed to investors so that it has an impact on stock prices.

\subsection{Stock Prices}

Stock price is the nominal that must be paid for each share and the end of the stock price is seen from the closing price on the day or the last time the stock market operates. Stock price can reflect the value of the company because the value of the company is seen how much the company's revenue and the number of assets owned so that the stock price is valued as a reflection of the value of the company. Stock prices are the price that occurs in the stock market at a certain time determined by the demand and supply of shares offered in the capital market (Hartono, 2015, p.188).

\subsection{Development of Hypotheses}

Bankruptcy prediction has a relationship with stock prices where bankruptcy is an understanding that the company fails to achieve its goals so that the company's stock price may be worthless. Bankruptcy predictions can estimate the stock price movements that will occur it is supported by Wiyarni (2018) bankruptcy predictions affect stock prices. The reason for bankruptcy prediction can affect stock prices is the valuation and trust in the company's shares in achieving its goals. Based on the description above, it can be concluded the hypothesis that: 
H1: Bankruptcy prediction has a direct significant effect on stock prices.

In addition, there are other factors that affect stock prices, namely EPS, because the more profits obtained by shareholders can increase the desire to own company shares and make company shares rise, so the concept why EPS can affect stock prices. Based on the description above, it can be concluded the hypothesis that:

$\mathrm{H} 2$ : Bankruptcy prediction has an indirect significant effect on stock prices through earnings per share.

\subsection{Research Scheme}

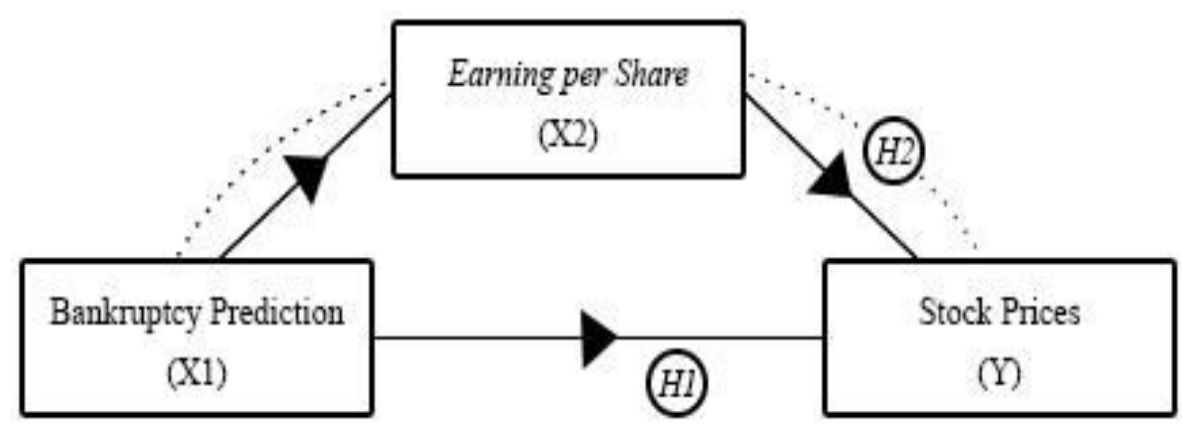

\section{METHODOLOGY}

This study uses secondary data, data available from other parties. The data analyzed in this study were taken from the bank's financial statements from the main website of PT. Bank Mandiri (Persero) Tbk. financial reports can be downloaded from www.bankmandiri.co.id and stock price history from www.idx.co.id or http://finance.yahoo.com.

\subsection{Operationalization of Variables}

The dependent variable in this research is stock price using data from the closing price. Then independent variable is a bankruptcy prediction model from Altman Z-Score modified for non-manufacturing firms. The formula is:

$Z=6.56(X 1)+3.26(X 2)+6.72(X 3)+1.05(X 4)$

$\mathrm{X} 1=N W C \div$ Total Assets 
$\mathrm{X} 2=$ Retained Earnings $\div$ Total Assets

$\mathrm{X} 3=\mathrm{EBIT} \div$ Total Assets

X4 = Book Value of Equity $\div$ Book Value of Liabilities

(Altman et al., 2017)

The last variable is earning per share as an intervening variable, the formula used to calculate EPS is as follows:

EPS $=\frac{\text { Net Income }}{\text { Total of Shares Outstanding }}$

\subsection{Data Analysis Method}

The test will use program application SPSS 23 with path analysis.

$\mathrm{Y} 1=\mathrm{px} 1 \mathrm{x} 2+\mathrm{px} 2 \mathrm{y} 1+\mathrm{e}$

Where:

Y1 : Stock Price

$\mathrm{X} 1$ : Bankruptcy Prediction

X2 : Earnings Per Share

$\mathrm{p}$ : Path Analysis

px1x2 : Coefficient path direct $X 1$ to $X 2$

px2y1 : Coefficient path direct $X 2$ to $Y 1$

\section{RESULT AND DISCUSSION}

\subsection{Normality Test}

This test is to find out whether the data is normally distributed or not and for the terms of the regression analysis test that is by way of Kolmogorov Smirnov (K$\mathrm{S})$, the significant value must be below 0.05 as a condition of normality or by looking at the results of the probability plot image with a decision if a small dot follows a diagonal line then declared distributed normal.

Table 1. Kolmogorov-Smirnov Test

One-Sample Kolmogorov-Smirnov Test

Unstandardized Residual

\begin{tabular}{|c|c|c|}
\hline $\mathrm{N}$ & & 47 \\
\hline \multirow[t]{2}{*}{ Normal Parameters ${ }^{a, b}$} & Mean & .0000000 \\
\hline & Std. Deviation & 752.41821030 \\
\hline \multirow[t]{2}{*}{ Most Extreme Differences } & Absolute & .091 \\
\hline & Positive & .061 \\
\hline
\end{tabular}




\begin{tabular}{lrr}
\hline & Negative & -.091 \\
\hline Test Statistic & .091 \\
\hline Asymp. Sig. (2-tailed) & & $.200^{\mathrm{c}, \mathrm{d}}$ \\
\hline
\end{tabular}

Source: Reseacher, Output SPSS, 2020

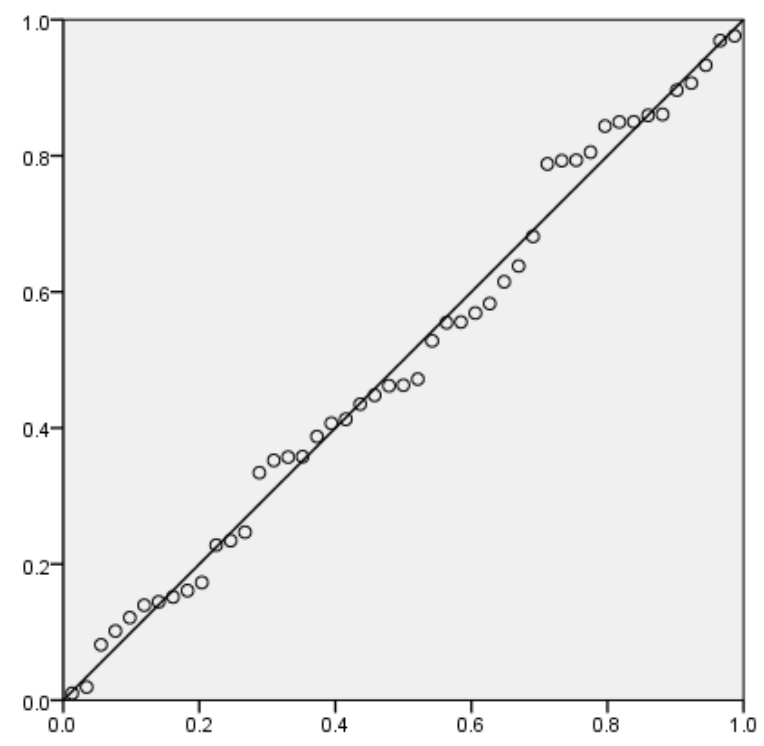

Figure 2. Probability Test

Source: Reseacher, Output SPSS, 2020

Based on the K-S results in the table and the probability plot image, we can find out that the data is normally distributed due to a significant value of 0.2 meaning $>0.05$ and on the small point picture follows a diagonal line.

\subsection{Heteroscedasticity Test}

This test uses a glacier test with the criterion of a significant value above a value of 0.05 so that it can be said that heteroscedasticity did not occur and successfully met the requirements.

Table 2. Glejser Test

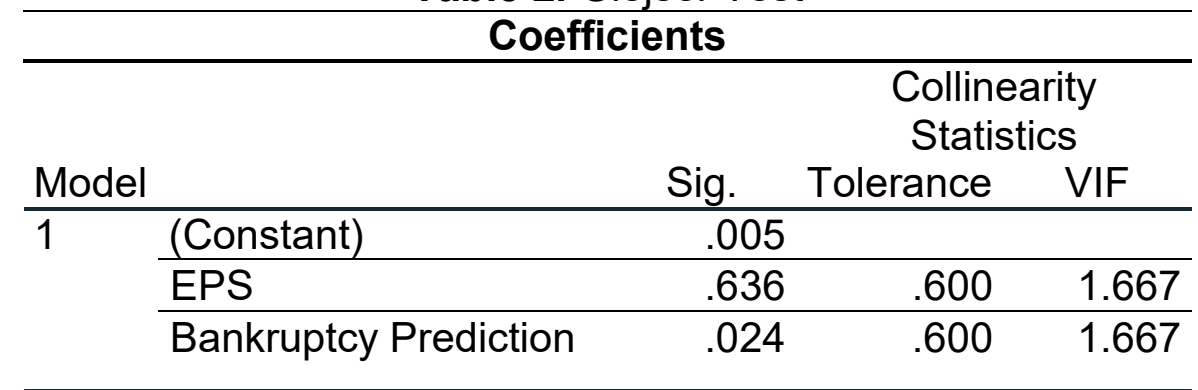

Source: Reseacher, Output SPSS, 2020 
Based on the table above, it can be stated that there is no heteroscedasticity in the data, which is significant in the EPS variable 0.636 and 0.024 bankruptcy prediction variables $>0.05$.

\subsection{Multicollinearity Test}

This test aims to determine whether the data occurs heteroscedasticity through tolerance and VIF based on tolerance decisions $>0.100$ and VIF $<10.00$.

Table 3. Multicollinearity Test

\begin{tabular}{|c|c|c|c|c|}
\hline \multicolumn{5}{|c|}{ Coefficients } \\
\hline \multirow[b]{2}{*}{ Mod } & & \multirow[b]{2}{*}{ Sig. } & \multicolumn{2}{|c|}{$\begin{array}{l}\text { Collinearity } \\
\text { Statistics }\end{array}$} \\
\hline & & & Tolerance & VIF \\
\hline 1 & (Constant) & .005 & & \\
\hline & EPS & .636 & .600 & 1.667 \\
\hline & Bankruptcy Prediction & .024 & .600 & 1.667 \\
\hline
\end{tabular}

Source: Reseacher, Output SPSS, 2020

Based on the multicollinearity test results table, it can be stated to meet the criteria because the requirements are met, meaning there is no multicollinearity event.

\subsection{Autocorrelation Test}

This test is performed to determine whether the data occurs autocorrelation in the data used. Decision making by: $d u<d w<4-d u$

Table 4. Autocorrelation Test Durbin's Two-Step

\begin{tabular}{llcccc}
\hline \multicolumn{7}{c}{ Model Summary $^{\mathbf{b}}$} \\
\hline Model & $\mathrm{R}$ & $\mathrm{R}$ & Adjusted R & Std. Error of & Durbin- \\
Square & Square & the Estimate & Watson \\
\hline 1 & $.055^{\mathrm{a}}$ & .003 & -.043 & .05029 & 2.012 \\
\hline \multicolumn{5}{c}{ Source: Reseacher, Output SPSS, 2020 }
\end{tabular}

Based on the results table above, it can be seen that there is no autocorrelation in the data cause du $(1.6204)<\mathrm{dw}(2.012)<4-\mathrm{du}(2.3796)$ 


\subsection{T-Test}

This test is to obtain information on whether there is an influence of each independent variable on the dependent variable directly.

Table 5. T-Test

\begin{tabular}{llcr}
\hline \multicolumn{4}{c}{ Coefficients $^{\mathbf{a}}$} \\
\hline \multirow{3}{*}{ Model } & $\mathrm{t}$ & Sig. \\
\hline 1 & (Constant) & -3.360 & .002 \\
\cline { 2 - 4 } & EPS & -4.584 & .000 \\
\cline { 2 - 4 } & Bankruptcy & 6.436 & .000 \\
& Prediction & & \\
\hline \multicolumn{4}{l}{ Source: Reseacher, Output SPSS, 2020 }
\end{tabular}

t-test results table, it can be stated that it is seen that there is a significant effect of bankruptcy predictions on stock prices due to a significant value $<0.05$.

\subsection{Sobel Test} variables.

This test is to obtain information on indirect effects through intervening

\begin{tabular}{|c|c|c|c|c|}
\hline Input: & & Test statistic: & Std. Error: & $p$-value: \\
\hline \begin{tabular}{l|l} 
a & 1361.258183
\end{tabular} & Sobel test: & -3.51573928 & 1636.40401204 & 0.00043853 \\
\hline$b-4.226362$ & Aroian test: & -3.48178973 & 1652.35993617 & 0.00049807 \\
\hline $\begin{array}{ll}S_{\mathrm{a}} 248.461785 \\
\end{array}$ & Goodman test: & -3.55070168 & 1620.29096849 & 0.00038421 \\
\hline \begin{tabular}{l|l}
$s_{b}$ & 0.921972
\end{tabular} & Reset all & & Calculate & \\
\hline
\end{tabular}

Figure 3. Sobel Test Calculation

Source: Reseacher, 2020

Based on the calculation of the Sobel test, it is known that the p-value is 0.0004 which means $<0.05$ then based on the $p$-value and the value of 0.05 can be interpreted that there is a mediating influence of earnings per share of the relationship of bankruptcy prediction on stock prices. 


\section{CONCLUSION}

There is a significant influence of bankruptcy predictions on stock prices in PT. Bank Mandiri (Persero) Tbk. And there is a significant influence of bankruptcy predictions on stock prices through earnings per share or an indirect effect between bankruptcy predictions on stock prices mediated by earnings per share at PT. Bank Mandiri (Persero) Tbk.

\section{REFERENCE}

Altman, E.I., Iwanicz-Drozdowska, M., Laitinen, E.K. and Suvas, A., 2017. Financial Distress Prediction in an International Context: A Review and Empirical Analysis of Altman's Z-Score Model. Journal of International Financial Management and Accounting, 28(2), pp.131-171.

Hartono, J., 2015. Teori portofolio dan analisis investasi. 10th ed. Yogyakarta: BPFE Universitas Gajah Mada.

Kapil, S. and Agarwal, S., 2019. Assessing Bankruptcy of Indian Listed Firms Using Bankruptcy Models, Decision Tree and Neural Network. International Journal of Business and Economics, 4(1), pp.112-136.

Nuryanto, A.D., Sulistiyono, A. and Pujiono, 2019. State-Owned Enterprises Restructuring Through Holding Company in Responding to Bankruptcy in Subsidiaries. Advances in Social Science, Education and Humanities Research, 358(lcglow), pp.179-182.

Panchal, M.H., Bodar, M.B., Maurya, S.R. and Tatwadarshi, P., 2019. An Innovative Approach to Predict Bankruptcy. VIVA-Tech International Journal for Research and Innovation, 1(2), pp.1-6.

Pradhan, R.S. and Paudel, L., 2016. Impact of fundamental factors on stock price: A case of Nepalese commercial banks. [online] Available at: <https://papers.ssrn.com/sol3/papers.cfm?abstract_id=3044108>.

Puspita, E., 2017. Pengaruh Likuiditas, Profitabilitas, Leverage, dan Market Ratio terhadap Dividend Payout Ratio pada Perusahaan Manufaktur. Ekuilibrium: Jurnal IImiah Bidang Ilmu Ekonomi, 12(1), pp.17-35.

Sharma, N. and Vyas, R., 2017. The Insolvency and Bankruptcy Code, 2016 - an overview. International Journal of Law, 3(6), pp.58-61.

Syamni, G., Majid, M.S.A. and Siregar, W.V., 2018. Bankruptcy Prediction Models and Stock Prices of the Coal Mining Industry in Indonesia. Etikonomi, 17(1), pp.57-68. 
Velankar, N., Chandani, A. and Ahuja, A.K., 2017. Impact of EPS and DPS on Stock price: A Study of Selected Public Sector Banks of India. Prestige International Journal of Management \& IT-Sanchayan, [online] 6(1), pp.111121. Available at: <http://pjitm.com/Doc/jan-july2017/PAPER8.pdf>.

Wiyarni, C.A.M., 2018. Z-Score Bankruptcy Prediction Model and Stock Prices of The Cigarette Companies in Indonesia. www.ijbmm.com International Journal of Business Marketing and Management, [online] 3(10), pp.2456-4559. Available at: <www.ijbmm.com>. 